\title{
LIFE SKILLS OF PRE-SERVICE TEACHERS: A COMPARATIVE STUDY
}

Shweta Gupta, (Research Scholar)

V.M.L.G (P.G.) College, Ghaziabad, U.P., C.C. S. University, Meerut, U.P. ORCID: 0000-0002-0918-0031

Email: shwetagupta1580@gmail.com

\section{Electronic version}

URL: http://www.researchinspiration.com

DOI: https://doi.org/10.53724/inspiration/v6n2.04

ISSN: 2455-443X

Vol. 6, Issue-II, March 2021

Page No. 13- 25

Publisher

Welfare Universe

Electronic reference/Article is to be Cited:

Shweta Gupta, (2021). Life Skills Of Pre-Service Teachers: A Comparative Study. Research Inspiration: An International Multidisciplinary e-Journal, ISSN 2456-443X, 6(II), 13-25.

https://doi.org/10.53724/inspiration/v6n2.04

CResearch Inspiration: An International Multidisciplinary e-Journal 2021. This Open Access article is published under a Creative Commons Attribution Non-Commercial 4.0 International License https://creativecommons.org/licenses/by-nc/4.0/, which permits non-commercial reuse, distribution, and reproduction in any medium, provided the original work is properly cited. For citation use the DOI. For commercial re-use, please contact editor email:- publish1257@gmail.com By accessing the work you hereby accept the Terms. Non-commercial uses of the work are permitted without any further permission from Research Inspiration: An International Multidisciplinary eJournal provided the work is properly attributed.

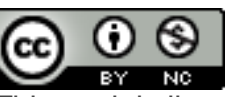

This work is licensed under a Creative Commons Attribution-NonCommercial 4.0 International License. 
Shweta Gupta, (Research Scholar)

V.M.L.G (P.G.) College, Ghaziabad, U.P., C.C. S. University, Meerut, U.P. ORCID: 0000-0002-0918-0031

Email: shwetagupta1580@gmail.com

\begin{abstract}
Teachers have a pivotal role in our education system. However, inefficiency in teachers can affect the very foundation of this education system and which in turn will lead to the downfall of society and the nation. It is well said that the quality of education depends on the quality of teachers, so it is essential to prepare a quality teacher. As the teacher acts as transmitter of knowledge, motivator, and manager so it is dire need to train the prospective teacher in Life skills. According to WHO life skills have been defined as "the abilities for adaptive and positive behaviour that enables individuals to deal effectively with the demands and challenges of everyday life". The present study include ten Life skills as suggested by WHO i.e. Self-awareness skill, Interpersonal skill, Effective Communication skill, Problem Solving, Decision Making, Critical Thinking, Creative Thinking, Coping with Stress, Coping with Emotion, and Empathy. A descriptive survey method is used for this study. The data of 100 pre-service teachers in which 40 female and 60 male pre-service teachers, were collected by random cluster sampling technique from two B.Ed. colleges of Ghaziabad affiliated to C.C.S. University Meerut in Ghaziabad district. Moreover, t-test is used as a statistical technique to compare the life skills between male and female preservice teachers. However, the investigator found no significant difference between the male and female pre-service teachers in their Life Skills.
\end{abstract}

Keywords: Life skills, Male and female pre-service teachers, Self- Awareness skill, Interpersonal skill, Effective Communication skill, Problem solving skill, Decision making skill, Critical Thinking Skill, creative thinking skill, Empathy, Coping with Stress, Coping with Emotion.

\title{
Introduction
}

In the new millennium, education is undergoing a revolutionary change in the field of science, technology, globalization, industrialization, privatization, urbanization etc. There is a cutthroat competition; unemployment and lack of job security etc. are challenging issues for today's youth. The youth are considered as the productive members of our society due to their physical and intellectual capabilities. But they are not using their potential and capabilities in a proper way due to the lack of proper guidance and counseling. These leads to some social problems like alcoholism, drug abuse, sexual abuse smoking, juvenile delinquency, anti-social acts, and crimes which have an adverse effect on them as well as on others. So, these require some efforts from our socially responsible education system which enables a person to live life happily and efficiently. An individual has some goals in their life, to achieve these goals a person should require some skills in them. These skills enable a person to face the challenging issues in the economical, technological, and social field of demographic society. These skills 
are known as the Life Skills which enable us to live life happily and successfully. No doubt the need for life skills is well addressed by different policy makers, educationists, teachers and by stakeholders. They all try to include these Life skills in the curriculum of school subjects, but the training of these Life Skills is hardly found in the curriculum other than subject knowledge. Moreover, it is found there is more stress on the developmental knowledge of prime subjects rather than development of any Life Skills which is in fact more important for life. Today's life becomes more mechanical, and it becomes impossible for the parents to become role models for their children, so it becomes the responsibility of teachers to develop different Life Skills in their students. At the end, it is the duty of teachers to train their students in life skills. Teachers have a pivotal role in our education system, so inefficiency of teachers can lead to the downfall of society and the nation. Teacher's philosophy, method of teaching, content knowledge, communication skill, class management skills, command on language, coping with emotion, mental ability, aptitude, and attitude all are not only essential for the progress of a teacher but also our society and nation. It is also well said that the quality of Education depends on the quality of teachers, so it is essential to prepare a quality teacher. As the teacher acts as transmitter of knowledge, motivator, and manager so it is dire need to train the prospective teacher in Life skills.

What are the Life Skills: In 1977 WHO stated life skill "A group of psycho-social competence and interpersonal skills that help people to make informed decision, solve problems, think creatively and critically, communicate effectively, build healthy relationship, emphasize with others and cope with stress and their emotion and manage their life in a healthy and productive manner. These abilities help an individual in the promotion of mental well-being and social competence to face hard realities of life."

UNESCO in 2001 conceptualized life skills as a person's ability to maintain a state of mental well-being and to demonstrate the same in adaptive and positive behaviour while interacting with others or his environment. It has been widely recognized that the development of life skills should be the primary concern of education,

UNICEF defines life skills as a behaviour change or behaviour development approach designed to address a balance of three areas: knowledge, attitude, and skills.

The world health organization defines life skills as "the abilities for adaptive and positive behaviour that enables an individual to deal effectively with demand and challenges of daily life."

UNICEF, UNESCO and WHO list ten core life skills strategies and techniques as: Problem solving, Decision making skill, Critical thinking, Interpersonal relationship, Self-awareness, Interpersonal relationship, Effective communication Skill, Empathy, Coping with stress and Coping with emotions

Self-Awareness Skill- It is the process of introspection and includes recognition of oneself. In other words, self-awareness is a way of exploring our self, our behaviour, nature, our habits, our characteristics, our strengths and weaknesses, our likes and dislikes, our beliefs, values and attitude, our inclination towards something and our options and shortcomings.

Developing self-awareness helps people to recognize the feeling of stress or being under the pressure. Furthermore, it is also a prerequisite for effective communication, interpersonal relationships and developing empathy for others.

Interpersonal Relationship- It is an ability in which a person interacts with the people positively. It also enables a person having friendly, happily, purposeful living. Human relationships have key importance in social as well as psychological perspective. Interpersonal relationship represents the relationship between 
two or more individuals that can range from short-lived to long-lasting. Moreover, it also implies our responsibilities towards the relationship. Interpersonal relationships can include both personal and professional relationships such as relations with our family, friends, relatives, and relations with our colleagues.

Effective communication skill- It is the ability in which one can express themselves both verbally and non-verbally in that way which suits to culture and circumstances. A person conveys his intended thought, ideas, feelings, expectation and plans in meaningfully politely and assertively to others. It not only includes expressing our thoughts but also our needs and fear i.e., we can ask for advice and help at the time of need. Effective communication is the group of different skills that allows a person to deliver and receive information effectively. Therefore, effective communication cannot be achieved by just using the verbal communication, but usually requires a combination of other skills.

Problem Solving Skill- Problem solving skills enables a person to identify the problem first, its sources and causes. Then the causes are eliminated in the first stage. After this the person makes alternative solutions for this and then the best one is adopted. Problem solving ability enables an individual to solve the problem effectively and timely without difficulty. Considered as the complex intellectual process, it has been defined as the high order cognitive process which involves regulation and control of daily routine work with some fundamental skills.

Decision Making Skill- It helps an individual to deal constructively with decisions about his life. In which a person weighs the advantage and disadvantage of a situation and its future consequences. Decision making involves a thinking process in which a number possible and alternative solutions are generated. Egan (1998) suggested that decision Making is a five steps sequential process which included Identification and definition of problem, which Develop alternative solutions, Evaluating alternatives, Implement the chosen alternatives and Evaluate the results.

Critical Thinking- It is an ability to see the positive and negative dimensions of any information and experiences in an objective manner i.e., without the influence of any biases. Critical thinking also contributes to our health by helping us recognize the factors which influence our attitude and values.

Creative thinking- The ability to think new and original from the available information is known as creative thinking. A person thought diversely. Creativity may be considered novel ways of thinking. Novel ideas can be generated through brainstorming, visualizing situations, seeing the relationship between situations and also by making analogies. A creative person can give different solutions to any problem.

Coping with stress: Stress is usually the result of the strain caused both mentally and physically. Stress usually can happen due to one of three causes; i.e. Pressure, Conflict and Frustration. Stress can be the byproduct of the situation when a person is being forced or pressurized either mentally or physically to do something, out of their will. Moreover, stress can also arise when one has to make a difficult choice in a very sensitive situation or condition, creating a conflict in their mind. One of the other reasons for stress can also be due to the frustration. This mainly occurs when a person is not able to communicate their problems and feelings due to the situations or the absence of the means of communication.

Stress can mostly lead to anger which can in turn lead to the emotional and physical destruction of themselves or to others. Moreover, coping with stress allows an individual to manage their stress by handling these three factors in order to act responsively in different situations. 
Coping with Emotion: Emotion is an English word, however, it has been derived from the word "Emouvoir", which originated from the "Emovere" a Latin word. In Emovere E means "out" and movere" means "move". An emotion is the representation of the mental and physiological picture of an individual. Emotions of an individual are mostly spontaneous and unconscious. Moreover, they are related with their feelings, thoughts and behaviour. There are different kinds of emotions that have been identified such as fear, sadness, happiness and anger, empathy etc. Coping with emotions is a mental/cognitive and behavioural effort made by an individual in order to deal with these both positive and negative emotions which can usually arise from the internal and external demands/expectations which are beyond their capacity.

Empathy: Empathy is an ability of an individual to understand another person's situation that is not familiar to us and also accept and understand the feelings of others. Empathy is considered as the selfless and noble act and is mostly related to interpersonal skill. Even though it comes naturally to some people, it can still be developed with the help of practice. Being empathetic allows an individual to improve their imagination in order to understand the world from a different perspective. This in turns allows an individual to significantly improve the social interaction with the people of different cultures and values.

\section{Review of related literature}

Patel A. (2012) conducted her study on life skills of male and female student teachers in Kerala district. She found female student teachers possess more life skill in comparison to male student teachers and there was a significant difference between academic anxiety of male and female student teachers, however, females possess more academic anxiety than male. ${ }^{2}$

Prema N. (2013) in her paper about the enforcement of life skills in teacher trainees by teacher educators and found that female teacher educators possessed a high level of life skills and teaching maximum possible life skills to their students in comparison to male teacher educator. ${ }^{3}$

Sandhu, Rakesh (2014) in his study on Life skills of pupil teachers found that most of the pupil teachers possess average level of life skills and a significant difference was found in life skills of male and female pupil teachers. While streamwise comparison science stream students possess more life skills than art students. 4

Bakır, S., \& Öztekin, E. (2014) in their study on creative thinking level of pre science teachers found no significant differences with respect to gender, year of study, type of schooling or graduated from and their parent's qualification. ${ }^{5}$ Kurtdede Fidan, N. (2018) in her study on an Investigation of pre-service teacher's life skills in terms of various variables found that female preservice teachers show more empathy and self-awareness skill than male preservice teachers and also reveals that as their grade increases, preservice teachers show low coping strategy regarding to their stress and emotion. ${ }^{6}$ Koyuncu, B. (2018) investigated on The Effect of Pre-Service Teachers' Life Skills on Teacher Self-Efficacy, and found a strong positive correlation between the life skills of pre-service teachers and their self-efficacy and no difference found in self-efficacy of male and female, graduate non-graduate and also trained or untrained in life skills training pre-service teachers. ${ }^{7}$

Susilo, H., Sudrajat, A. K., \& Rohman, F. (2021) in their study on the importance of developing creativity and communication skills for teacher: Prospective teacher students perspective found that all the student agreed on that it is essential to develop communication skill and creativity in preservice teachers. ${ }^{8}$

Arasomwan, D. A., \& Mashiya, N. (2021) on their study on Foundation phase pre-service teachers' 
experiences of teaching life skills during teaching practice found that they experience support from their mentor but finding struggle with the implementation of FP curriculum and also lack of awareness for the importance of life skills as a subject and suggested to improve the pedagogy of future LS teachers. ${ }^{9}$

\section{Main Objective}

To compare Life Skills of male and female Pre-service teachers.

\section{Sub Objectives}

1.1. To compare the Self-awareness life skill of male and female Pre-Service teachers.

1.2. To compare the Interpersonal skill of male and female Pre-Service teachers.

1.3 To compare Effective communication skill of male and female Pre-Service teachers.

1.4 To compare Problem -solving skill of male and female Pre-Service teachers.

1.5 To compare Decision- making skill of male and female Pre-Service teachers.

1.6 To compare Critical thinking skill of male and female Pre-Service teachers.

1.7 To compare Creative thinking skill of male and female Pre-Service teachers.

1.8 To compare Coping with the stress skill of male and female Pre-Service teachers.

1.9 To compare Coping with emotion skill of male and female Pre-Service teachers.

1.10. To compare Empathy skill of male and female Pre-Service teachers.

\section{Hypotheses}

Ho1- There is no significant difference between the life skills of male and female Pre -service teachers

\section{Sub Hypotheses}

Ho1. 1 There is no significant difference between Self-awareness skill of male and female pupil teachers.

Ho1. 2. There is no significant difference between the Interpersonal skill of male and female pupil teachers.

Ho1. 3. There is no significant difference between the Effective communication skill of male and female Pre-service teachers.

Ho1. 4. There is no significant difference between the Problem-solving skill of male and female Preservice teachers.

Ho1. 5. There is no significant difference between the Decision-making skill of male and female Preservice teachers.

Ho1. 6. There is no significant difference between the Critical thinking skill of male and female Preservice teachers.

Ho1. 7. There is no significant difference between the Creative thinking skill of male and female Preservice teachers.

Ho1. 8. There is no significant difference between the Coping with stress skill of male and female Preservice teachers.

Ho1. 9. There is no significant difference Coping with the emotion skill of male and female Pre-service teachers.

Ho1. 10. There is no significant difference between the Empathy skill of male and female Pre-service teachers.

\section{Research Methodology and Sample}

The data for the study was collected by Descriptive survey method. Random cluster method of sampling 
technique was used to draw out representative data of Pre- Service Teachers. The data of 100 pre-service teachers in which 40 female and 60 male pre-service teachers, were collected from two B.Ed colleges of Ghaziabad affiliated to C.C.S. University Meerut in Ghaziabad district.

\section{Tool used:}

A self-constructed research tool (Life skills Scale) is used by the investigator to study the life skills of male and female pre-service Teachers on ten life skills suggested by WHO.

\section{Statistical Techniques Used}

For data analysis $t$ test, mean and standard deviation is calculated.

\section{Data Analysis and Interpretation}

\section{Main Objective - To compare Life Skills of male and female Pre-service teachers.}

To achieve this objective, the data was collected from pre-service teachers from IPEM B.Ed. college of Ghaziabad district. In order to achieve this objective, a null hypothesis was formulated that there is no significant difference between the life skills of male and female Pre-service teachers.

To test this hypothesis, the data regarding life skills were tabulated and analysed by using t-test. The result for this analysis is shown below in Table 1.1

\section{Data analysis:}

The table shows the mean, standard deviation, t-test value with level of significance for both male and female pre-service teachers.

\begin{tabular}{|c|c|c|c|c|c|c|}
\hline $\begin{array}{c}\text { Life Skills } \\
\text { dimensions }\end{array}$ & Male mean & $\begin{array}{c}\text { Female } \\
\text { mean }\end{array}$ & $\begin{array}{c}\text { Male } \\
\text { Standard } \\
\text { deviation }\end{array}$ & $\begin{array}{c}\text { Female } \\
\text { Standard } \\
\text { deviation }\end{array}$ & t-value & $\begin{array}{c}\text { Level of } \\
\text { Significance }\end{array}$ \\
\hline Life Skills & 333.83 & 340.5 & 57.98 & 48.42 & 0.59 & NS \\
\hline
\end{tabular}

Table: 1.1 The table shows the mean and standard deviation of total life skills for both female and male Pre-service teachers. Moreover, it also shows the $t$-value with its level of significance based on the detected p-value for all ten life skills. NS= Not significant.

\section{Hypothesis testing:}

The objective of this hypothesis was to compare the life skills of male and female pre-service teachers. To achieve this objective, a null hypothesis was formulated and tested using t-test statistics. The null hypothesis was that there is no significant difference between the life skills of male and female preservice teachers.

\section{Discussion:}

As shown in table 1.1 above, the mean for the male and female pre-service teachers were found to be 333.83 and 340.50 , respectively. This indicates that the mean score for both male and female are similar. The $\mathrm{t}$-value between the life skill of male and female pre-service teachers was found to be 0.59 . The $\mathrm{t}$ value is smaller than the t-critical value at $95 \%$ confidence i.e. 1.96 at $95 \%$ confidence. This means that the t-value is not significant. As the t-value is found to be not significant therefore our null hypothesis, that there is no significant difference between the life skills of male and female pre-service teachers, is accepted. This means that there is no significant difference between the life skills of male and female preservice teachers of B.Ed. colleges. This analysis concluded that male and female Pre-service teachers of B.Ed. colleges of Ghaziabad district have similar level of life skills. 


\section{Sub Objectives- Comparison of Life skills between Male and Female Pre-service teachers}

To detect the significant difference of ten life skills between male and female pre-service teachers, the $\mathrm{t}$ test statistics was used on the collected data of 100 pre-service teachers in which there were 60 male and 40 female pre-service teachers.

\begin{tabular}{|c|c|c|c|c|c|c|}
\hline $\begin{array}{l}\text { Life Skills } \\
\text { dimensions }\end{array}$ & Male mean & $\begin{array}{l}\text { Female } \\
\text { mean }\end{array}$ & $\begin{array}{c}\text { Male } \\
\text { Standard } \\
\text { deviation }\end{array}$ & $\begin{array}{l}\text { Female } \\
\text { Standard } \\
\text { deviation }\end{array}$ & t-value & $\begin{array}{l}\text { Level of } \\
\text { Significanc } \\
\text { e }\end{array}$ \\
\hline Life Skills & 333.83 & 340.5 & 57.98 & 48.42 & 0.59 & NS \\
\hline Self-awareness & 33.08 & 33.3 & 5.24 & 4.31 & 0.21 & NS \\
\hline Interpersonal & 27.7 & 28.35 & 6.23 & 5.15 & 0.54 & NS \\
\hline $\begin{array}{c}\text { Effective } \\
\text { Communication }\end{array}$ & 35.53 & 35.55 & 5.96 & 5.62 & 0.01 & NS \\
\hline Problem Solving & 27.63 & 29.1 & 5.63 & 4.29 & 1.39 & NS \\
\hline Decision Making & 32.32 & 32.77 & 6.11 & 6.02 & 0.37 & NS \\
\hline Critical Thinking & 39.5 & 39.62 & 7.89 & 7.27 & 0.08 & NS \\
\hline $\begin{array}{l}\text { Creative } \\
\text { Thinking }\end{array}$ & 30.58 & 30.18 & 5.61 & 4.85 & 0.37 & NS \\
\hline $\begin{array}{l}\text { Coping with } \\
\text { Stress }\end{array}$ & 35.52 & 36.7 & 8.71 & 7.6 & 0.69 & NS \\
\hline $\begin{array}{l}\text { Coping with } \\
\text { Emotion }\end{array}$ & 35.08 & 37.27 & 8.17 & 8.7 & 1.27 & NS \\
\hline Empathy & 36.88 & 37.65 & 6.57 & 6.08 & 0.58 & NS \\
\hline
\end{tabular}

Sample size $(N)=100$, $t$-critical value at $95 \%$ confidence level is 1.96

Table: 1.2 the table shows the mean and standard deviation of each of ten life skills and the total life skill for both female and male pupil teachers. Moreover, it also shows the t-test value with its level of significance based on the detected p-value for all ten life skills. NS= Not significant.

\section{Hypothesis 1.1}

This hypothesis states that there is no significant difference between the self-awareness skill of male and female pre-service teachers.

Discussion:

As shown in table 1.2 above, the mean for the male and female pupil teachers were found to be 33.08 and 33.3, respectively. This indicates that the mean score for both male and female are similar.

The t-value between self-awareness skill of male and female pupil teachers was found to be 0.21 .The $t$ value is smaller than the $\mathrm{t}$-critical value at $95 \%$ confidence which is 1.96 at $95 \%$ confidence. This means that the t-value is not significant. As the t-value is found to be not significant therefore our null hypothesis, that there is no significant difference between the self-awareness skill of male and female pupil teachers, is accepted. This means that there is no significant difference between the self-awareness skill of male and female pre-service teachers of B.Ed. college.

\section{Hypothesis 1.2}

This hypothesis states that there is no significant difference between the interpersonal skill of male and female pre-service teachers 


\section{Discussion:}

As shown in table 1.2 above, the mean for the male and female pupil teachers were found to be 27.7 and 28.35 respectively. This indicates that the mean score for both male and female are similar.

The t-value between interpersonal skill of male and female pre-service teachers was found to be 0.54 . The $\mathrm{t}$-value is smaller than the $\mathrm{t}$-critical value at $95 \%$ confidence which is 1.96 at $95 \%$ confidence. This means that the t-value is not significant. As the t-value is found to be not significant therefore our null hypothesis, that there is no significant difference between the interpersonal skill of male and female preservice teachers, is accepted. This means that there is no significant difference between the interpersonal skill of male and female pre-service teachers of B.Ed. college.

\section{Hypothesis 1.3}

This hypothesis states that there is no significant difference between the effective communication skill of male and female pre-service teachers.

\section{Discussion:}

As shown in table 1.2, the mean for the male and female pre-service teachers were found to be 35.53 and 35.55 respectively. This indicates that the mean score for both male and female are similar.

The t-value between effective communication skill of male and female pre-service teachers was found to be 0.01 . The $\mathrm{t}$-value is smaller than the $\mathrm{t}$-critical value at $95 \%$ confidence which is 1.96 at $95 \%$ confidence. This means that the $\mathrm{t}$-value is not significant. As the $\mathrm{t}$-value is found to be not significant therefore our null hypothesis, that there is no significant difference between the effective communication skill of male and female pre-service teachers, is accepted. This means that there is no significant difference between the effective communication skill of male and female pre-service teachers of B.Ed. college.

\section{Hypothesis 1.4}

This hypothesis states that there is no significant difference between the problem-solving skill of male and female pre-service teachers.

\section{Discussion:}

As shown in table 1.2 above, the mean for the male and female pre-service teachers were found to be 27.63 and 29.1 respectively. This indicates that the mean score for both male and female are similar.

The $\mathrm{t}$-value between problem solving skill of male and female pre-service teachers was found to be 1.39. The $\mathrm{t}$-value is smaller than the t-critical value at $95 \%$ confidence which is 1.96 at $95 \%$ confidence. This means that the $\mathrm{t}$-value is not significant. As the $\mathrm{t}$-value is found to be not significant therefore our null hypothesis, that there is no significant difference between the problem-solving skill of male and female pre-service teachers, is accepted. This means that there is no significant difference between the problem solving skill of male and female pre-service teachers of B.Ed. college.

\section{Hypothesis 1.5}

This hypothesis states that there is no significant difference between the decision-making skill of male and female pre-service teachers.

\section{Discussion:}

As shown in table 1.2 above, the mean for the male and female pre-service teachers were found to be 32.32 and 32.77 respectively. This indicates that the mean score for both male and female are similar.

The t-value between decision making skill of male and female pre-service teachers was found to be 0.37 . 
The $\mathrm{t}$-value is smaller than the $\mathrm{t}$-critical value at $95 \%$ confidence which is 1.96 at $95 \%$ confidence. This means that the t-value is not significant. As the t-value is found to be not significant therefore our null hypothesis, that there is no significant difference between the decision -making skill of male and female pre-service teachers is accepted. This means that there is no significant difference between the decision making skill of male and female pre-service teachers of B.Ed. college.

\section{Hypothesis 1.6}

This hypothesis states that there is no significant difference between the critical thinking skill of male and female pre-service teachers.

\section{Discussion:}

As shown in table 1.2 above, the mean for the male and female pre-service teachers were found to be 39.5 and 39.62 respectively. This indicates that the mean score for both male and female are similar.

The t-value between critical thinking skill of male and female pre-service teachers was found to be 0.08 . The $\mathrm{t}$-value is smaller than the t-critical value at $95 \%$ confidence which is 1.96 at $95 \%$ confidence. This means that the t-value is not significant. As the t-value is found to be not significant therefore our null hypothesis, that there is no significant difference between the critical thinking skill of male and female pre-service teachers, is accepted. This means that there is no significant difference between the critical thinking skill of male and female pre-service teachers of B.Ed. college.

\section{Hypothesis 1.7}

This hypothesis states that there is no significant difference between the creative thinking skill of male and female pre-service teachers.

\section{Discussion:}

As shown in table 1.2 above, the mean for the male and female pre-service teachers were found to be 30.58 and 30.18 respectively. This indicates that the mean score for both male and female are similar.

The t-value between creative thinking skill of male and female pre-service teachers was found to be 0.37 . The $\mathrm{t}$-value is smaller than the t-critical value at $95 \%$ confidence which is 1.96 at $95 \%$ confidence. This means that the $\mathrm{t}$-value is not significant. As the t-value is found to be not significant therefore our null hypothesis, that there is no significant difference between the creative thinking skill of male and female pre-service teachers, is accepted. This means that there is no significant difference between the creative thinking skill of male and female pre-service teachers of B.Ed. college.

\section{Hypothesis 1.8}

This hypothesis states that there is no significant difference between the coping with stress skill of male and female pre-service teachers.

\section{Discussion:}

As shown in table 1.2 above, the mean for the male and female pre-service teachers were found to be 35.52 and 36.7 respectively. This indicates that the mean score for both male and female are similar.

The t-value between coping with stress skill of male and female pre-service teachers was found to be 0.69. The $\mathrm{t}$-value is smaller than the $\mathrm{t}$-critical value at $95 \%$ confidence which is 1.96 at $95 \%$ confidence. This means that the t-value is not significant. As the t-value is found to be not significant therefore our null hypothesis, that there is no significant difference between the coping with stress skill of male and female pre-service teachers, is accepted. This means that there is no significant difference between the coping with stress skill of male and female pre-service teachers of B.Ed. college. 


\section{Hypothesis 1.9}

This hypothesis states that there is no significant difference between the coping with emotion skill of male and female pre-service teachers.

\section{Discussion:}

As shown in table 1.2 above, the mean for the male and female pre-service teachers were found to be 35.08 and 37.27 respectively. This indicates that the mean score for both male and female are similar.

The $\mathrm{t}$-value between coping with emotion skill of male and female pre-service teachers was found to be 1.27, The t-value is smaller than the t-critical value at $95 \%$ confidence which is 1.96 at $95 \%$ confidence. This means that the t-value is not significant. As the t-value is found to be not significant therefore our null hypothesis, that there is no significant difference between the coping with emotion skill of male and female pre-service teachers, is accepted. This means that there is no significant difference between the coping with emotion skill of male and female pre-service teachers of B.Ed. college.

\section{Hypothesis 1.10}

This hypothesis states that there is no significant difference between the empathy skill of male and female pre-service teachers.

\section{Discussion:}

As shown in table 1.2 above, the mean for the male and female pre-service teachers were found to be 36.88 and 37.65 respectively. This indicates that the mean score for both male and female are similar.

The $\mathrm{t}$-value between empathy skill of male and female pre-service teachers was found to be 0.58 . The $t-$ value is smaller than the $\mathrm{t}$-critical value at $95 \%$ confidence which is 1.96 at $95 \%$ confidence. This means that the t-value is not significant. As the $\mathrm{t}$-value is found to be not significant therefore our null hypothesis, that there is no significant difference between the empathy skill of male and female preservice teachers, is accepted. This means that there is no significant difference between the empathy skill of male and female pre-service teachers of B.Ed. college.

\section{Discussion and Conclusion}

Today's time is the time for equality, there is no difference in males and females. Both genders are getting equal opportunity to grow in every dimension of their life. They are aware of their choices and responsibilities. Moreover, they both are trying equally, to grow both in their personal and professional life. This can also be seen in the teaching profession, where both male and female pre-service teachers are choosing teaching professions due to their interest in the teaching rather than just a job opportunity. Therefore, they are also trying to make equal effort to grow in different skills, whenever required. This can also be seen in the finding where the investigator found no significant difference in the level of life skills in both male and female pre-service teachers. This study is supported by Pramod and Celine (2011), where they detected no significant difference in the life skills of male and female student teachers of Kerala (10), however in Antony (2008), study female teacher trainees show higher level of life skills than their counterpart. ${ }^{11}$

- Male and female pre- service teachers did not show any significant difference in their Self-awareness skills as both are equally aware of their strengths and weaknesses.

- Male and female pre- service teachers did not show any significant difference in their Interpersonal skills as it can be assumed that both have an equal relationship with their students. This finding was 
supported by Bhardwaj (2013), who found no difference in interpersonal skill of male and female student teachers. ${ }^{12}$

- Male and female pre- service teachers did not show any significant difference in effective communication skills as both are equally good in their communication skill.

- Male and female pre- service teachers did not show any significant difference in their ProblemSolving skills as both have the same level of problem- solving skills. This finding was supported by Yenice (2011), where it has been reported that there was no significant difference observed between male and female pre-service science teachers, on their problem-solving skills. ${ }^{13}$

- Male and female pre- service teachers did not show any significant difference in their Critical thinking skills. This study is supported by Tümkaya (2009), who found no significant difference in critical thinking skill of male and female university students. ${ }^{14}$

- Male and female pre- service teachers did not show any significant difference in their Creative Thinking skills. This finding was supported by Bakır and Öztekin (2014) who reported that there is no significant difference in Creative Thinking skill of male and female preservice science teachers. ${ }^{15}$

- Male and female pre- service teachers did not show any significant difference in their Coping with stress skills. This finding is supported by Jayachitra. J. (2015) who reported no difference in stress management skill of male and female B.Ed. students. ${ }^{16}$

- Male and female pre- service teachers did not show any significant difference in their Coping with emotion skills as both can control their emotion equally.

- Male and female pre- service teachers did not show any significant difference in their Empathy skills as both have the same empathy for others.

\section{Educational implications}

\section{For Administrators And Supervisors}

- The administration of college may be using the finding of the study to provide equal opportunities for both and female pre -service teachers for training.

- From the above findings the principal of schools may provide a good working environment in the school for better enhancement of life skills. Time to time the administration may arrange different courses for life skills development in the college.

\section{$>$ For Policymakers}

The policymaker may use this finding to arrange all the essential activities to enhance life skills in pupil teachers. As it is well said that skills can be cultivated and enhanced through training so they may organize different workshops on life skills training either in a pre-service program or in-service teaching and arranging seminars for enhancement of life skills in them.

\section{$>$ For Teacher Educators}

To provide a good level of life skill during the training program, teacher educators may use different techniques such as group discussion, and brainstorming methods e.g., during teaching, to inculcate different life skills in pupil teachers. They should provide a friendly environment during their teaching and give more time to inculcate life skills in pupil teachers.

\section{References}

1. Egan, G. (1998), The skilled helper: A problem-management approach to helping. Pacific Grove, Calif: Brooks/Cole

2. Patel, A. C. (2012), LIfe Skills and Acadamic Anaxiety of student teachers, Indian Stream Research joural, 2(10). 
3. Prema, N (2013), Enforcing Life skills to Teacher Trainees by Teacher Educators, Indian Journal of Research, 2(8), 70-71.

4. Sandhu, R. (20144, July -September), A study of Life Skills of Pupil Tachers, Indian Journal of Fundamental and Applied Sciences, 4(3), 389-395.

5. Bakır, S., \& Öztekin, E. (2014), CREATIVE THINKING LEVELS OF PRESERVICE SCIENCE TEACHERS IN TERMS OF DIFFERENT VARIABLES, Journal of Baltic Science Education, 13(2), 12.

6. Kurtdede Fidan, N. (2018), AN INVESTIGATION OF PRESERVICE TEACHERS' LIFE SKILLS IN TERMS OF VARIOUS VARIABLES. https://doi.org/10.5281/zenodo.1467422

7. Koyuncu, B. (2018), The Effect of Pre-Service Teachers' Life Skills on Teacher Self-Efficacy, Journal of Education and Learning, 7(5), 188-200.

8. Susilo, H., Sudrajat, A. K., \& Rohman, F. (2021), The importance of developing creativity and communication skills for teacher: Prospective teacher students perspective, AIP Conference Proceedings, 2330(1), 030059, https://doi.org/10.1063/5.0043157

9. Arasomwan, D. A., \& Mashiya, N. (2021), Foundation phase pre-service teachers' experiences of teaching life skills during teaching practice. South African Journal of Childhood Education, 11(1), https://doi.org/10.4102/sajce.v11i1.700

10. Pramod. D and Celines Pereira. (2011), A study on the level of life skills of student teacher of kerala, Indian Journal of Liife Skills Education, 2(2), 389-399.

11. Antony, S. V. (2008), Life skills Attributes in Teacher Trainees, (Mahesh Bhargava and Haseen Taj ed.), Agra: Horizon of Teacher Education.(167-173)

12. Bhardwaj, S. (2013). Teaching skills study skills and life skills among student teachers in relation to their sex and stream of study at graduation level, University, http://shodhganga.inflibnet.ac.in:8080/jspui/handle/10603/128025

13. Yenice, N. (2011), Investigating pre-service science teachers' critical thinking dispositions and problem-solving skills in terms of different variables, 12 .

14. Tümkaya S., Aybek, B., \& Aldağ, H. (2009), An investigation of university students' critical thinking disposition and perceived problem-solving skills, Egitim Arastirmalari-Eurasian Journal of Educational Research, 36, 57-74

15. Bakır, S., \& Öztekin, E. (2014), CREATIVE THINKING LEVELS OF PRESERVICE SCIENCE TEACHERS IN TERMS OF DIFFERENT VARIABLES, Journal of Baltic Science Education, 13(2), 12.

16. Jayachitra.J.(2015), Life Skills of Bed. Students In Relation To Their Teaching Performance, University. http://shodhganga.inflibnet.ac.in:8080/jspui/handle/10603/93458 